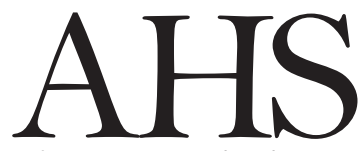

Advances in Horticultural Science
OPEN ACCESS

(*) Corresponding author:

raniaaydi@yahoo.fr

Citation:

AYDI-BEN-ABDALLAH R., NAWAIM AMMAR, FAKHER AYED, HAYFA JABNOUN-KHIAREDDINE, MEJDA DAAMI-REMADI., 2021 - Single and combined effects of Bacillus spp. and brown seaweed (Sargassum vulgare) extracts as bio-stimulants of eggplant (Solanum melongena L.) growth. - Adv. Hort. Sci., 35(2): 151-164

\section{Copyright:}

(C) 2021 Aydi-Ben-Abdallah R., Nawaim Ammar, Fakher Ayed, Hayfa Jabnoun-Khiareddine, Mejda Daami-Remadi. This is an open access, peer reviewed article published by Firenze University Press (http://www.fupress.net/index.php/ahs/) and distributed under the terms of the Creative Commons Attribution License, which permits unrestricted use, distribution, and reproduction in any medium, provided the original author and source are credited.

Data Availability Statement:

All relevant data are within the paper and its Supporting Information files.

Competing Interests:

The authors declare no competing interests.

Received for publication 25 August 2020 Accepted for publication 28 May 2021

\title{
Single and combined effects of Bacillus spp. and brown seaweed (Sargassum vulgare) extracts as bio-stimulants of eggplant (Solanum melongena L.) growth
}

\author{
R. Aydi-Ben-Abdallah ${ }^{1(*)}$, N. Ammar ${ }^{1}$, F. Ayed ${ }^{1,2}$, H. Jabnoun- \\ Khiareddine ${ }^{1}$, M. Daami-Remadi ${ }^{1}$ \\ 1 LR21AGR03-Production and Protection for a Sustainable Horticulture, \\ University of Sousse, Regional Research Centre on Horticulture and \\ Organic Agriculture, BO 57, 4042 Chott-Mariem, Tunisia. \\ 2 Technical Centre of Organic Agriculture, 4042 Chott-Mariem, Sousse, \\ Tunisia.
}

Key words: Bacillus spp., bio-stimulant, compost tea, eggplant growth, extracts, Sargassum vulgare.

Abstract: Bacillus subtilis SV41, B. amyloliquefaciens subsp. plantarum SV65 and Sargassum vulgare extracts were evaluated for their plant growth-promoting potential on eggplant (Solanum melongena L.) plants. Bio-treatments applied singly and/or in combination were further compared to a compost tea and to a commercial bio-fertilizer $\left(\right.$ Acadian $^{\mathrm{TM}}{ }^{\text {}}$ ). Results clearly showed that the combined treatments based on the two Bacillus spp. strains and the aqueous algal extract and the last one mixed with $B$. amyloliquefaciens subsp. plantarum SV65 induced the highest enhancements in the plant height and the maximum root length which were estimated at 32.4-33.9\%, 23.9-25.5\% and 23.4-25\% and at 36.8-41\%, 32.9-37.4\% and 36.3-40.5\% compared to water, compost tea and Acadian $^{\mathrm{TM}}$ based treatments, respectively. Furthermore, the combined treatment based on the aqueous algal extract and B. amyloliquefaciens subsp. plantarum SV65 had significantly improved eggplant growth where the recorded increments in the stem diameter, the aerial part fresh weight, and the root fresh weight varied from 17.5 to $24.6 \%, 38.4$ to $46.1 \%$, and 32.3 to $50 \%$ as compared to the three controls, respectively. As for single treatments tested, the aqueous extract had induced a significant improvement in the major growth parameters measured. Developed bio-stimulant was found to be more effective than compost tea and commercial bio-fertilizer based treatments.

\section{Introduction}

The eggplant (Solanum melongena L.) contributes to the diversification of market gardening products and constitutes a new product requested by foreign markets. In Tunisia, the exported quantities over the past five 
years were estimated at 187 tons. The export rate remains low compared to 56 thousand tons recorded in 2013/2014 agricultural campaign concentrated in tomato, watermelon, potato, and salad crops. To meet the requirements of consumers and increase the competitiveness of our exports at the international markets level, significant efforts have been made in terms of improving quality and productivity of this crop (GIL, 2020).

The increasing demand for eggplants has gone along with the rapid population growth (Maghfoer et al., 2014). Eggplants contain low calories and high nutrient potential (Sowinska and Krygier, 2013). According to Gandhi and Sundari (2012), eggplant is widely used for medicinal features to reduce blood cholesterol and to regulate hypertension. Thus, due to these benefits, the demand of eggplant and its production is expected to increase (Sowinska and Krygier, 2013).

Long term use of inorganic fertilizer has altered soil fertility leading to decreased efficiency of nutrient absorption and productivity and adverse effects on environment and human health (Jagatheeswari, 2013; Waseem et al., 2013). Therefore, research efforts are concentrated on alternative nutrients to improve soil physical, chemical, and biological traits through the application of chimerical organic fertilizers (Maghfoer et al., 2014) and/or various organic soil amendments such as compost (D'Hose et al., 2012), plant extracts (Bijarniya, 2011), algae (Eyras et al., 2008), and microbial inoculants (Arora et al., 2020). Application of chemical fertilizers with inoculants has been also explored (Carvajal-Muñoz and Carmona-Garcia, 2012). Application of microbial inoculants has gained an increased interest in the last three decades (Babalola and Glick, 2012).

Microbial inoculants are the formulations of beneficial living microorganisms that, when added to the soil, they can improve the availability of nutrients to host plant either directly or indirectly, thereby leading to improved plant growth (Gaind, 2011). Various microorganisms are explored for the production of microbial inoculants such as Azotobacter, Azospirillum, Bradyrhizobium, mycorrhizae, phosphorus solubilizing bacteria, and Rhizobium. These bioinoculants can colonize the soil and perform various biophysical and biochemical soil activities that facilitate the availability and the uptake of nutrients to plants (Alori et al., 2017). Microbial inoculants could be grouped into nitrogen fixers i.e. Rhizobium and Bradyrhizobium, phosphate solubilizers i.e.
Pseudomonas, Bacillus, Aspergillus etc., cellulose degraders such as Cytophaga, and phosphate mobilizers such as mycorrhizae.

Recent demands of organic farming enhanced the application of organic treatments such as seaweed extracts in agriculture. Seaweeds are aquatic plants belonging to the plant kingdom of Thallophyta (Arioli et al., 2015). At least 59 species of seaweeds can stimulate germination, growth, and yields of some horticultural plants (Sunarpi et al., 2010). Seaweed application in the agricultural field has numerous benefits such as stimulation of seed germination, promoting plant growth, improvement of water and nutrient uptake, enhancement of frost and saline resistance, biocontrol and resistance towards phytopathogenic agents, and remediation of pollutants of contaminated soil (Nabti et al., 2016). Fresh and dry seaweed or its derived products i.e extracts, composts, and soil conditioners, have been long used in agriculture to enhance plant growth and productivity (Eyras et al., 2008). Seaweeds applied, singly or in combination with other macroalgae and/or bacteria, enhance crop productivity. Sridhar and Rengasamy (2010) successfully applied a brown marine alga $S$. wightii combined with a green seaweed Ulva lactuca to enhance peanut growth. Additionally, a mixture of two bacteria Azotobacter chrocoocum and Bacillus megaterium var. phosphaticum combined with seaweed extracts increased growth of bitter orange plants (Ismail et al., 2011).

In view of previous studies, aqueous and methanolic extracts from a brown macroalgae (S. vulgare) were assessed singly and in combination with two endophytic bacteria i.e $B$. subtlis SV14 and $B$. amyloliquefaciens subsp. plantarum SV65 for eggplant growth. Both Bacillus spp. used in this study showed growth and health bio-stimulating effects on tomato plants through their capacity to produce indole-3-acetic acid, organic acids siderophore and their ability to solubilize phosphate and to biocontrol Fusarium wilt disease in tomato (Aydi Ben Abdallah et al., 2017, 2018). Furthermore, Ammar et al. (2017) demonstrated $S$. vulgare aqueous and methanolic extracts' ability to efficiently control Fusarium dry rot disease in potato. Phenolic acids and flavonoids are the major components in the methanolic extract of $S$. vulgare using HPLC-DAD analysis (Ammar et al., 2017).

The main objective of this study was to evaluate the ability of two Bacillus spp. strains applied singly and/or combined with S. vulgare aqueous or 
methanolic extracts on eggplant growth and productivity.

\section{Materials and Methods}

\section{Bacillus spp. Culture}

B. subtilis SV41 (Accession number KR818071) and B. amylolequifaciens subsp. plantarum SV65 (Accession number KR818073) isolated from two wild Solanaceous species Datura metel and Solanum nigrum, respectively, were used in this study. Their isolation protocol, characterization and identification analysis were mentionned in Aydi Ben Abdallah et al., (2017) and (2018) studies. They were previously selected based on their growth bio-stimulating effect and ability to control tomato Fusarium wilt disease when tested in pot experiment or under field conditions (Aydi Ben Abdallah et al., 2017; 2019). The plant growth-promoting traits of both Bacillus strains are detailed in Table 1.

Stock cultures of both bacterial strains, were conserved at $-20^{\circ} \mathrm{C}$ in Nutrient Broth (NB) medium amended with $40 \%$ glycerol. Bacillus spp. colonies of a 1-day-old culture on Nutrient Agar (NA) medium were transferred to Luria-Bertani broth (LB) and incubated at $28 \pm 2^{\circ} \mathrm{C}$ for $48 \mathrm{~h}$ and under continuous shaking at $150 \mathrm{rpm}$. The bacterial strains were tested at the exponential stage of growth (data unpublished). The concentration of Bacillus spp. was adjusted at $10^{8}$ cells $/ \mathrm{ml}$ using spectrophotometre at DO $600 \mathrm{~nm}$.

Table 1 - Plant growth-promoting (PGP) traits of Bacillus subtilis SV41 and Bacillus amyloliquefaciens subsp. plantarum SV65 used in the current investigation (Aydi Ben Abdallah et al., 2017, 2019)

\begin{tabular}{lcc}
\hline & \multicolumn{2}{c}{ Bacterial strain } \\
\cline { 2 - 3 } PGP traits & $\begin{array}{c}\text { B. subtilis } \\
\text { SV41 }\end{array}$ & $\begin{array}{c}\text { B. amyloliquefa- } \\
\text { ciens subsp. } \\
\text { plantarum SV65 }\end{array}$ \\
\hline IAA production $^{z}$ & + & + \\
Phosphatase activity $^{y}$ & - & + \\
Organic acids $^{x}$ & + & + \\
Siderophore production $^{w}$ & + & + \\
\hline
\end{tabular}

${ }^{z} \mathrm{IAA}=$ Indole-3-acetic acid; +: Production of IAA.

$\mathrm{y}+=$ Presence of phosphatase activity; -: Absence of phosphatase activity.

$x=$ Organic acids; +: Production of oxalic and malic acids.

$w+=$ Presence of siderophore activity.
Preparation of aqueous and methanolic extracts from Sargassum vulgare

Brown seaweed was sampled during February 2014 from Monastir, Tunisia (N 3546'47.754"; E $\left.10^{\circ} 47^{\prime} 9.312^{\prime \prime}\right)$. The alga sampling and processing are detailed in a previous study (Ammar et al., 2017). Grounded samples were packed and stored at $4^{\circ} \mathrm{C}$ until use.

For aqueous extraction, $1 \mathrm{~kg}$ of powder sample of S. vulgare was soaked in $20 \mathrm{I}$ of sterile distilled water (SDW) and boiled at $100 \pm 2^{\circ} \mathrm{C}$ for $1 \mathrm{~h}$. After cooling, extracts were filtered twice through Whatman $\mathrm{N}^{\circ} 1$ sterile filter paper and further sterilized by filtration through sterile microfilter ( $0.22 \mu \mathrm{m}$ pore size). The collected aqueous extracts, prepared at the concentration $50 \mathrm{~g} / \mathrm{l}$, were stored at $4^{\circ} \mathrm{C}$ until further use within a week to avoid any chemical alteration (Ammar et al., 2017).

For methanolic extraction, samples of the brown seaweed (1 $\mathrm{kg}$ each) were subjected to a series of maceration in methanol (3 I) for three days under ambient room conditions. After filtration, the solvent was evaporated using a rotary evaporator under reduced pressure $\left(\right.$ at $60^{\circ} \mathrm{C}$ ). One gram of the methanolic dry residue was separately dissolved into $10 \mathrm{ml}$ of methanol. Methanolic extracts used at the concentration $1 \mathrm{~g} / \mathrm{l}$ were stored at $4^{\circ} \mathrm{C}$ until further use (Ammar et al., 2017).

\section{Eggplant seedling preparation}

The cultivar Bonica, the most used by agricultures in the Tunisian Centre-East regions, was used in this study.

Eggplant cv. Bonica seeds were disinfected by immersion into $0.2 \%$ sodium hypochlorite for $3 \mathrm{~min}$. They were washed several times with SDW. Disinfected seeds were subsequently treated with bacterial suspensions ( $\sim 10^{8}$ cells $/ \mathrm{ml}$ ) and/or aqueous and methanolic $S$. vulgare extracts using $20 \mu \mathrm{l}$ per seed for $1 \mathrm{~h}$. The same volume of SDW was used for treatment of control seeds.

Eggplant treated and untreated seeds were sown in alveolar plastic trays $(7 \times 7 \mathrm{~cm})$ filled with sterilized peat $^{\mathrm{Tm}}$ (Floragard VertriebsGmbH für gartenbau, Oldenburg). Seeds were further treated at trays with $5 \mathrm{ml}$ of bacterial suspensions ( $\sim 10^{8}$ cells $/ \mathrm{ml}$ ) and/or aqueous and methanolic extracts from the brown seaweed. Control seeds were treated with the same volume of SDW. During all the growing period, trays were watered regularly to avoid drought stress and seedlings were kept under greenhouse conditions $\left(20-30^{\circ} \mathrm{C}\right.$ with a $16 \mathrm{~h}$ light and $8 \mathrm{~h}$ dark cycle, and 60- 
$70 \%$ relative humidity) until reaching the two-true leaf growth stage.

Screening of the effects of Bacillus spp. and Sargassum vulgare extracts on eggplant growth

Effect of single bio-treatments

Each Bacillus spp. strain (B. subtilis SV41 or B. amyloliquefaciens subsp. plantarum SV65) was singly inoculated to eggplant seedlings by dipping roots for $30 \mathrm{~min}$ in a bacterial suspension $\left(10^{8} \mathrm{cells} / \mathrm{ml}\right)$ prepared as described above (Aydi Ben Abdallah et al., 2017). Control seedlings were dipped in SDW only and LB medium. Treated and control seedlings were transplanted into individual pots $(12.5 \mathrm{~cm} \times 14.5 \mathrm{~cm})$ containing sterilized peat. Treated seedlings were retreated as substrate drenching with $50 \mathrm{ml}$ of each bacterial cell suspension or with $50 \mathrm{ml}$ of $S$. vulgare aqueous and methanolic extracts prepared as described above. Four weeks after transplanting, eggplant seedlings were re-treated with $50 \mathrm{ml}$ of each bacterial suspension and/or tested aqueous and methanolic extracts.

Seven replicates of one seedling each were used for each individual treatment and the whole experiment was conducted twice. Treated and control seedlings were grown for 60 days under greenhouse conditions as described above (Botta et al., 2013). After 60 days of growth, the plant height, the stem diameter, the aerial part fresh and dry weights, the maximum root length, the root fresh and dry weights, the flower number, the fruit number, and the fruit fresh and dry weights were noted.

\section{Effect of combined bio-treatments}

For combined bio-treatments, equal volumes of cell suspensions of each bacterial strain from $2 \mathrm{~d}$-old LB cultures were mixed and adjusted to $10^{8}$ cells $/ \mathrm{ml}$ with SDW. Equal volumes of each aqueous and/or methanolic extract from the brown seaweed were mixed with an equal volume of bacterial suspension of $B$. subtilis SV41and B. amyloliquefaciens subsp. plantarum SV65 adjusted at $10^{8}$ cells $/ \mathrm{ml}$ or their combination. Seven combined bio-treatments were tested and detailed in Table 2.

Eggplant cv. Bonica seedlings were treated by dipping roots for $30 \mathrm{~min}$ in each combined bio-treatment prepared as described above. Control seedlings were dipped in SDW only and LB medium. Treated and control seedlings were potted in commercialized sterile peat. Treated seedlings were re-treated as substrate drenching with $50 \mathrm{ml}$ of each tested combined bio-treatment. Four weeks after transplanting, eggplant seedlings were re-treated with $50 \mathrm{ml}$ of each combined bio-treatment as described above.

Seven replicates of one seedling each were used for each individual treatment and the whole experiment was conducted twice. After 60 days of growth under the same greenhouse conditions, the same growth parameters detailed above were measured.

Comparative efficacy of tested bio-treatments (Bacillus spp. and Sargassum vulgare extracts) and organic amendments

Bacillus spp. strains and S. vulgare extracts even applied singly or in combination were compared to a compost tea and to a commercial bio-fertilizer for their growth-promoting potential on eggplant seedlings.

\section{Comparative efficacy of tested bio-treatments and a} compost tea

The compost used in this study contained $70 \%$ of bovine manure, $25 \%$ of sheep manure and $5 \%$ of olive-mill solid waste. The characterization of compost and the preparation procedure of compost tea $(1: 5 \mathrm{w} / \mathrm{v})$ were described in a previous study (Ayed et al., 2018). The physico-chemical and microbial characterization of compost are listed in Table 3. The compost used in this study had significantly improved the plant height, the leaf number, the aerial part dry

Table 2 - The seven combined bio-treatments tested

Bio-treatment

Bacillus subtilis SV41 + Bacillus amyloliquefaciens subsp. plantarum SV65

Sargassum vulgare aqueous extract $+B$. subtilis SV41

S. vulgare aqueous extract $+B$. amyloliquefaciens subsp. plantarum SV65

S. vulgare aqueous extract $+B$. subtilis SV41 + B. amyloliquefaciens subsp. plantarum SV65

S. vulgare methanolic extract $+B$. subtilis SV41

S. vulgare methanolic extract $+B$. amyloliquefaciens subsp. plantarum SV65

S. vulgare methanolic extract + B. subtilis SV41 + B. amyloliquefaciens subsp. plantarum SV65
Code of

bio-treatment

$B 1+B 2$
$E A q+B 1$
$E A q+B 2$
$E A q+B 1+B 2$
$E$ Meth + B1
E Meth + B2
Meth + B1 + B2


weight of tomato plants compared to the untreated control plant (Ayed et al. 2018).

Eggplant seedlings were treated by dipping roots for $30 \mathrm{~min}$ in compost tea (CT). Control seedlings were dipped in SDW only. Treated and control seedlings were transplanted into individual pots (12.5 $\times 14.5 \mathrm{~cm}$ ) containing sterilized peat. Treated seedlings were re-treated as substrate drenching with $50 \mathrm{ml}$ of compost tea. Four weeks after transplanting, eggplant seedlings were re-treated with 50 $\mathrm{ml}$ of compost tea.

After 60 days of growth under greenhouse conditions, the growth parameters were measured as described above.

Comparative efficacy of tested bio-treatments and a commercial bio-fertilizer

The commercial bio-fertilizer used in this study was the Acadian ${ }^{\text {tw }}$ seaweed extract powder used at 2 $\mathrm{g} / \mathrm{l}$. The procedure of seedling treatment, the greenhouse conditions and the noted growth parameters were the same as described above.

\section{Statistical analysis}

A one-way analysis of variance (ANOVA) was used for data analysis. The software used is the Statistical

Table 3 - The physico-chemical and microbial characterization

Physico-chemical characterization

\begin{tabular}{lc}
\hline Total organic carbon (\%) & 25 \\
Organic matter (\%) & 43 \\
Water retention (\%) & 33 \\
Total porosity (\%) & 50 \\
Bulk density $\left(\mathrm{g} / \mathrm{cm}^{3}\right)$ & 0.55 \\
Dry matter $(\%)$ & 70 \\
Electrical conductivity ( $\mathrm{mS} / \mathrm{cm})$ & 3.6 \\
Potential of Hydrogen (PH) & 7.3 \\
Ambient temperature $\left({ }^{\circ} \mathrm{C}\right)$ & $\sim 34$ \\
Nutrient content $(\%$ of Dry matter) & \\
Nitrogen (N) & 1.82 \\
Phosphorus (P) & 0.07 \\
Potassium (K) & 1.2 \\
Calcium (Ca) & 3.39 \\
Sodium (Na) & 0.59 \\
Microbial characterization & \\
Bacterial count ${ }^{2}$ (10 $\mathrm{CFU} / \mathrm{g}$ of compost) & 3.92 \\
Fungal count ${ }^{\mathrm{y}}\left(10^{4} \mathrm{CFU} / \mathrm{g}\right.$ of compost) & 6.6 \\
\hline
\end{tabular}

$z, y$ Bacteria and fungal counts from compost during the maturation phase of composting after $72 \mathrm{~h}$ of incubation at $35^{\circ} \mathrm{C}$ onto PCA and PDA, respectively.
Package for the Social Sciences (SPSS) for Windows version 16.0. Each Experiment was conducted twice yielding similar results. No significant interactions between treatment and experiment were noted. Therefore, one representative trial of each experiment is reported. Experiments were undertaken according to a completely randomized design. Means were compared using Multiple Range Duncan test at $\mathrm{P} \leq 0.05$.

\section{Results}

Growth-promoting potential of tested single biotreatments

B. subtilis SV41 and B. amyloliquefaciens subsp. plantarum SV65 based treatments and the aqueous and methanolic $S$. vulgare extracts were screened singly for their plant growth-promoting (PGP) ability on eggplant plants. As shown in Figs. 1, 2 and 3, the plant growth parameters (plant height, stem diameter, fresh and dry weight of the aerial part, maximum root length, root fresh weight, flower and fruit number, and fruit fresh weight), noted 60 days post-treatment, varied significantly (at $\mathrm{P} \leq 0.05$ ) depending on tested bacterial and/or algal extracts.

Plants treated separately with the whole bacterial cells of both Bacillus strains and the aqueous extracts from S. vulgare were significantly 19 to $29.2 \%$ taller than the untreated control plants (Fig. 1a). The treatments based on $B$. amyloliquefaciens subsp. plantarum SV65 cells, the aqueous and the methanolic extracts from the brown seaweed led to a significant increase by 14.3 to $20.9 \%$ in the stem diameter as compared to water control (Fig. 1b). Treatments with the methanolic and the aqueous algal extracts had stimulated by 33.8 and $43.4 \%$ the aerial part fresh over the untreated control (Fig. 1c). Only the aqueous extract had significantly enhanced the aerial part dry weight by $32.3 \%$ compared to control (Fig. 1d). It should be highlighted that eggplant aerial part development was similar for LB medium- treated plants and water control ones (Figs. 1a, 1b, 1c, 1d).

As for their effects on the root development, all tested bio-treatments induced a significant (at $\mathrm{P} \leq$ 0.05 ) increment in the maximum root length and the root fresh weight when compared to control (Figs. $2 \mathrm{a}, 2 \mathrm{~b})$. The maximum root length was significantly increased by 16.6 to $27.7 \%$ with both Bacillus spp. strains and $S$. vulgare aqueous extract when applied separately as compared to control (Fig. 2a). The root 

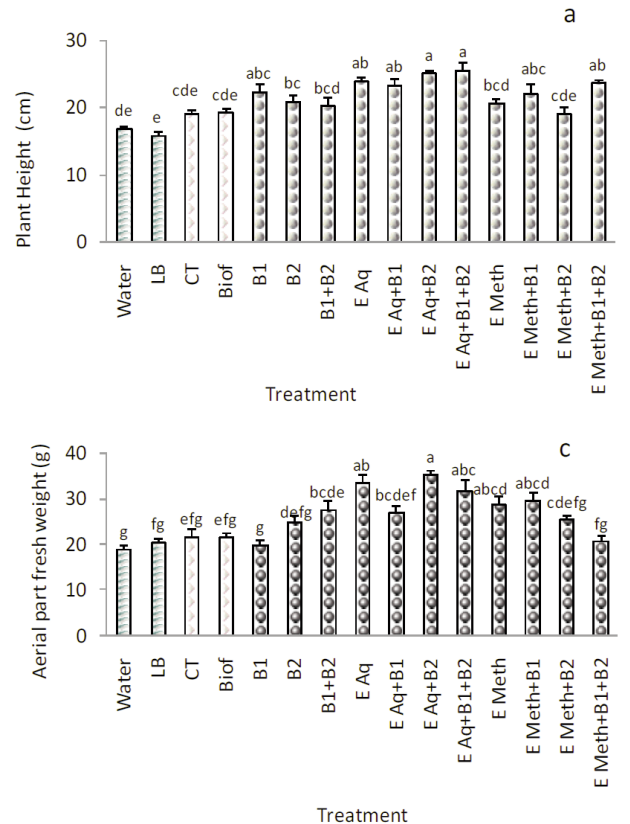
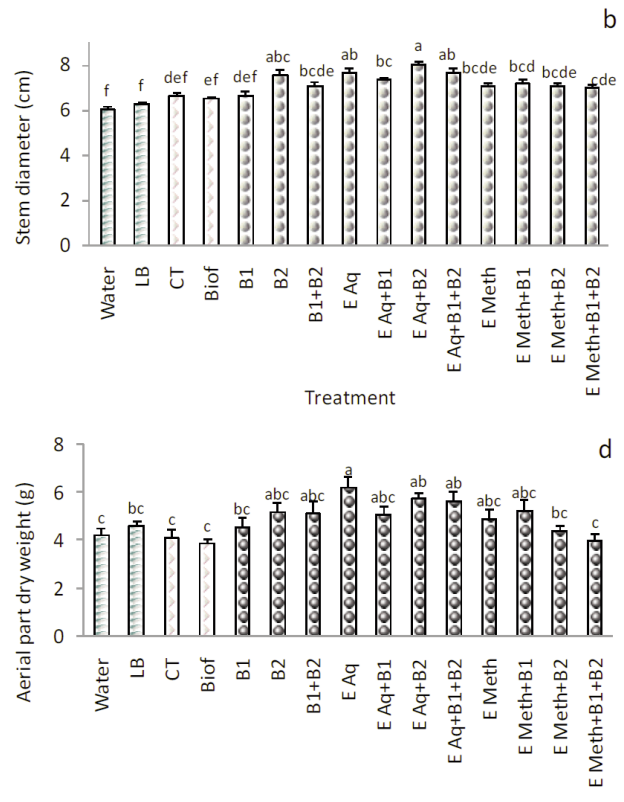

Treatment

Fig. 1 - Comparative efficacy of single and combined bio-treatments with Sargassum vulgare extracts and selected Bacillus spp. strains on the aerial part development of eggplant plants compared to the untreated control and to two organic amendments. Water= Plants treated with water; $L B=$ Plants treated with Luria-Bertani broth medium; $C T=$ Plants treated with a compost tea; Biof= Plants treated with a commercial bio-fertilizer $\left(\right.$ Acadian $\left.^{\mathrm{TM}}\right)$; B1= Single treatment with B. subtilis SV41; B2= Single treatment with B. amyloliquefaciens subsp. plantarum SV65; B1+B2=Combined treatment with B. subtilis SV41 and B. amyloliquefaciens subsp. plantarum SV65; E Aq: Single treatment with aqueous S. vulgare extract; $E A q+B 1=$ Combined treatment with $S$. vulgare aqueous extract and $B$. subtilis SV41; E Aq+B2= Combined treatment with aqueous $S$. vulgare extract and B. amyloliquefaciens subsp. plantarum SV65; $\mathrm{E} \mathrm{Aq+B1+B2=Combined} \mathrm{treatment} \mathrm{with} \mathrm{aqueous} S$. vulgare extract and both Bacillus spp. strains. E Meth= Single treatment with methanolic $S$. vulgare extract. E Meth+B1= Combined treatment with methanolic $S$. vulgare extract and $B$. subtilis SV41; E Meth+B2: Combined treatment with methanolic S. vulgare extract and B. amyloliquefaciens subsp. plantarum SV65; E Meth+B1+B2: Combined treatment with methanolic S. vulgare extract and both Bacillus spp. strains. Bars sharing the same letters are not significantly different according to Multiple Range Duncan test at 5\%. (a) Comparative efficacy of tested bio-treatments on eggplant height; (b) Comparative efficacy of tested bio-treatments on eggplant stem diameter; (c) Comparative efficacy of tested bio-treatments on eggplant aerial part fresh weight; (d) Comparative efficacy of tested bio-treatments on eggplant aerial part dry weight.

fresh weight was enhanced by 29.9 and $38.2 \%$ over control following treatments with B. amyloliquefaciens subsp. plantarum SV65 (B2) and S. vulgare methanolic extract, respectively (Fig. 2b). It should be highlighted that eggplant root development parameters were comparable on plants treated with LB medium as well as water control plants (Figs. 2a, 2b, 2c).

Data illustrated in figure 3a indicated a significant increase by 65.5 to $78.7 \%$ over the untreated control in the flower number following the individual application of all tested bio-treatments where the highest increment, of about $78.7 \%$ over control, was achieved using the algal aqueous extract. The fruit number was $30 \%$ higher than control in plants treated with the aqueous extract (Fig. 3b). Eggplant plants treated separately with $S$. vulgare extracts and the whole cell suspensions of $B$. subtilis SV41 showed $25.7-28.7 \%$ higher fruit fresh weight relative to con- trol (Fig. 3c). It should be highlighted that plants treated with LB medium behaved similar than water control plants for eggplant flower and fruit production (Figs. 3a, 3b, 3c, 3d).

\section{Growth-promoting potential of tested combined bio- treatments}

Seven combinations of the tested bio-treatments were evaluated for their effect on eggplant growth. Analysis of variance revealed a significant (at $P \leq$ $0.05)$ variation in the plant height, the stem diameter, the fresh and dry weights of the aerial part, the maximum root length, the root fresh weight, the flower number, and the fruit fresh weight, depending on tested treatments. As shown in figure 1a, a significant increment in plant height, by 23.7 to $33.9 \%$ compared to control, was noted on eggplant plants treated with $S$. vulgare aqueous extract combined with each of Bacillus strains (EAq+B1 and $E A q+B 2)$, 

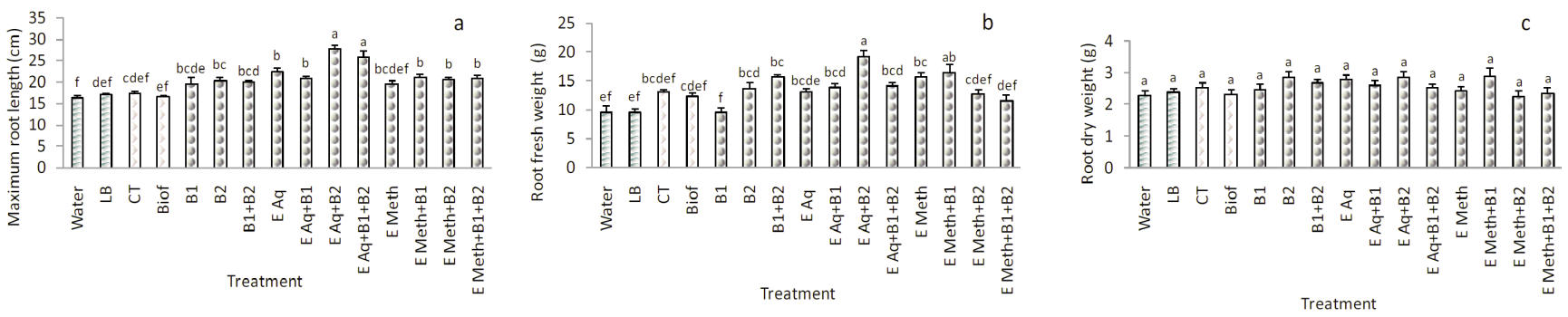

Fig. 2 - Comparative efficacy of single and combined bio-treatments with Sargassum vulgare extracts and selected Bacillus spp. strains on the root development of eggplant plants compared to the untreated control and to two organic amendments. Water= Plants treated with water; $L B=$ Plants treated with Luria-Bertani broth medium; CT= Plants treated with a compost tea; Biof= Plants treated with a commercial bio-fertilizer $\left(\right.$ Acadian $\left.^{\mathrm{TM}}\right)$; $\mathrm{B} 1=$ Single treatment with $B$. subtilis SV41; $\mathrm{B} 2=$ Single treatment with $B$. amyloliquefaciens subsp. plantarum SV65; B1+B2= Combined treatment with $B$. subtilis SV41 and B. amyloliquefaciens subsp. plantarum SV65; $E A q=$ Single treatment with aqueous $S$. vulgare extract; $E A q+B 1=$ Combined treatment with $S$. vulgare aqueous extract and $B$. subtilis SV41; E Aq+B2= Combined treatment with aqueous $S$. vulgare extract and B. amyloliquefaciens subsp. plantarum SV65; $\mathrm{E} \mathrm{Aq+B1+B2=Combined} \mathrm{treatment} \mathrm{with} \mathrm{aqueous} \mathrm{S.} \mathrm{vulgare} \mathrm{extract} \mathrm{and} \mathrm{both} \mathrm{Bacillus} \mathrm{spp.} \mathrm{strains.} \mathrm{E}$ Meth= Single treatment with methanolic $S$. vulgare extract. E Meth+B1= Combined treatment with methanolic $S$. vulgare extract and B. subtilis SV41; $\mathrm{E}$ Meth+B2= Combined treatment with methanolic $S$. vulgare extract and B. amyloliquefaciens subsp. plantarum SV65; $\mathrm{E}$ Meth+B1+B2= Combined treatment with methanolic $S$. vulgare extract and both Bacillus spp. strains. Bars sharing the same letters are not significantly different according to Multiple Range Duncan test at 5\%. (a) Comparative efficacy of tested bio-treatments on eggplant maximum root length; (b) Comparative efficacy of tested bio-treatments on eggplant root fresh weight; (c) Comparative efficacy of tested bio-treatments on eggplant root dry weight.
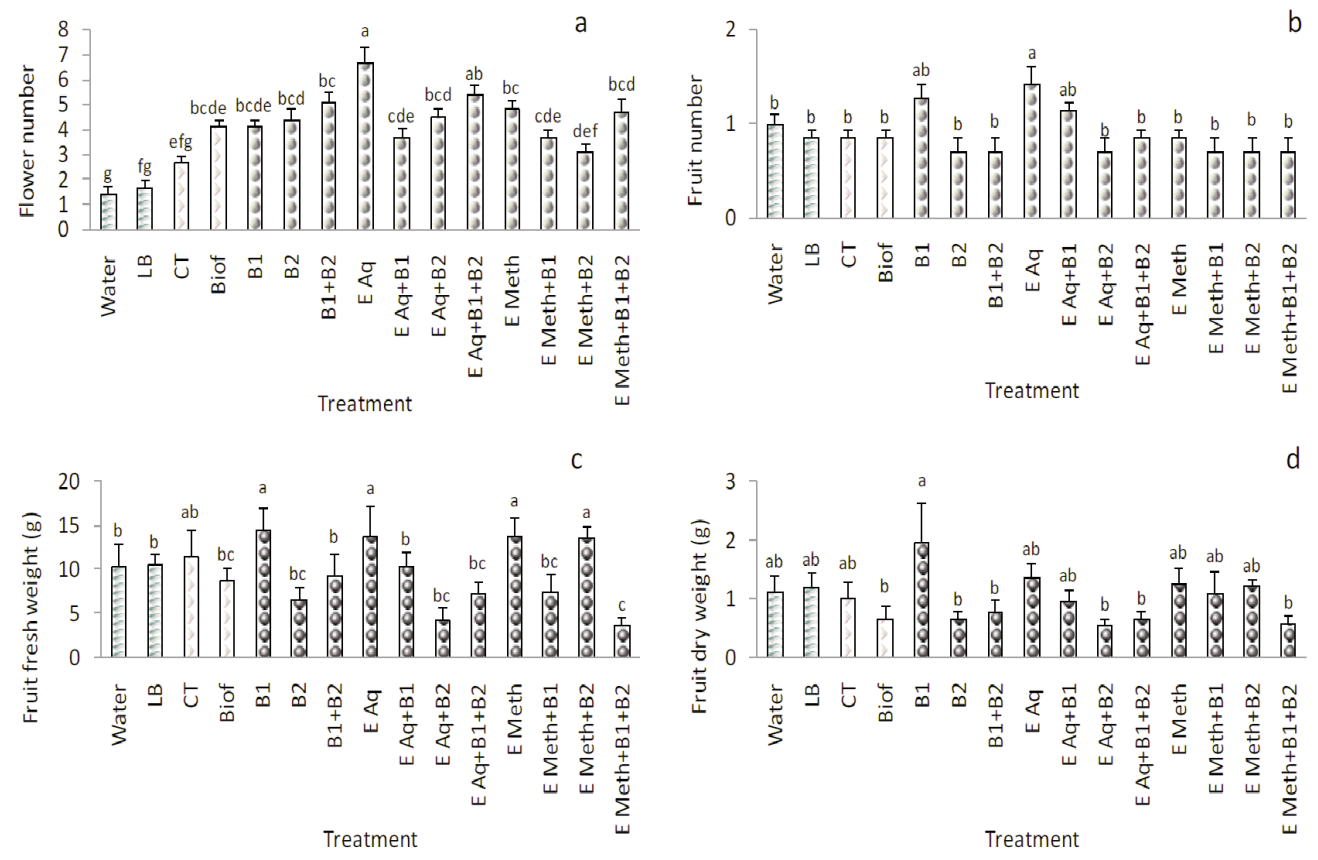

Fig. 3 - Comparative efficacy of single and combined bio-treatments with Sargassum vulgare extracts and selected Bacillus spp. strains on the eggplant flowers and fruit production compared to the untreated control and to two organic amendments. Water= Plants treated with water; $\mathrm{LB}=$ Plants treated with Luria-Bertani broth medium; $\mathrm{CT}=$ Plants treated with a compost tea; Biof $=$ Plants treated with a commercial bio-fertilizer $\left(\right.$ Acadian $\left.^{\mathrm{TM}}\right)$; $\mathrm{B} 1=$ Single treatment with $B$. subtilis SV41; $\mathrm{B} 2=$ Single treatment with $B$. amyloliquefaciens subsp. plantarum SV65; B1+B2= Combined treatment with $B$. subtilis SV41 and B. amyloliquefaciens subsp. plantarum SV65; E Aq= Single treatment with aqueous $S$. vulgare extract; $E A q+B 1=C o m b i n e d$ treatment with $S$. vulgare aqueous extract and $B$. subtilis SV41; $\mathrm{E} A \mathrm{Aq}+\mathrm{B} 2=$ Combined treatment with aqueous $S$. vulgare extract and B. amyloliquefaciens subsp. plantarum SV65; $\mathrm{E} A \mathrm{Aq}+\mathrm{B} 1+\mathrm{B} 2=$ Combined treatment with aqueous $S$. vulgare extract and both Bacillus spp. strains. $\mathrm{E}$ Meth= Single treatment with methanolic $S$. vulgare extract. E Meth+B1= Combined treatment with methanolic $S$. vulgare extract and $B$. subtilis SV41; $\mathrm{E}$ Meth+B2= Combined treatment with methanolic $S$. vulgare extract and B. amyloliquefaciens subsp. plantarum SV65; $\mathrm{E}$ Meth+B1+B2= Combined treatment with methanolic S. vulgare extract and both Bacillus spp. strains. Bars sharing the same letters are not significantly different according to Multiple Range Duncan test at 5\%. (a) Comparative efficacy of tested bio-treatments on eggplant flower number; (b) Comparative efficacy of tested bio-treatments on eggplant fruit number; (c) Comparative efficacy of tested bio-treatments on eggplant fruit fresh weight; $d$ : Comparative efficacy of tested bio-treatments on eggplant fruit dry weight. 
the aqueous and the methanolic algal extracts combined each one with both bacterial strains $(\mathrm{EAq}+\mathrm{B} 1+\mathrm{B} 2$ and $\mathrm{EMeth}+\mathrm{B} 1+\mathrm{B} 2)$ and the methanolic extract mixed with $B$. subtilis SV41 (EMeth+B1). The highest increase of this parameter, of about 32.4$33.9 \%$ over control, was recorded following treatments with $S$. vulagre aqueous extract combined with $B$. amyloliquefaciens subsp. plantarum SV65 $(E A q+B 2)$ and the algal aqueous extract mixed with the two Bacillus strains (EAq+B1+B2).

A significant enhancement of the stem diameter of the treated plants, estimated at 13.6 to $24.7 \%$ over control, was also noted following the seven tested combined bio-treatments. The highest increment (24.7\%) was induced by the aqueous extract combined with $B$. amyloliquefaciens subsp. plantarum SV65 $(E A q+B 2)$ and at a lesser extent this extract when mixed with both Bacillus strains $(\mathrm{EAq}+\mathrm{B} 1+\mathrm{B} 2)$ (20.9\%) (Fig. 1b).

The aerial part fresh weight was also significantly increased by 29.6 to $46.1 \%$ over control following treatments with the two bacterial strains $(B 1+B 2)$, the aqueous extract combined with each bacterial strain separately (namely $\mathrm{EAq}+\mathrm{B} 1$ and $\mathrm{EAq}+\mathrm{B} 2$ ) or in combination $(E A q+B 1+B 2)$ and the methanolic extract mixed with $B$. subtilis SV41 (EMeth+B1) (Fig. 1c). The highest increment (by $46.1 \%$ relative to the control) was induced by the aqueous extract combined with $B$. amyloliquefaciens subsp. plantarum SV65 (EAq+B2). Eggplant plants treated with the algal aqueous extract combined with $B$. amyloliquefaciens subsp. plantarum SV65 cells (EAq+B2) or mixed with both Bacillus strains $(\mathrm{EAq}+\mathrm{B} 1+\mathrm{B} 2)$ showed a significant enhancement in their aerial part dry weight by 25.4-26.5\% compared to control (Fig. 1d).

As shown in figure $2 \mathrm{a}$, the maximum root length increase over control ranged between and 18.4 to $41 \%$ following all tested combined bio-treatments and the highest improvement, of about $36.8-41 \%$ over control, was induced by $S$. vulgare aqueous extract mixed with both Bacillus strains (EAq+B1+B2) or with B. amyloliquefaciens subsp. plantarum SV65 $(\mathrm{EAq}+\mathrm{B} 2)$. All tested bio-treatments combined with the algal aqueous extract induced a significant enhancement in the root fresh weight of about 30.6$50 \%$ as compared to control (Fig. 2b). Furthermore, the combined treatment based on $S$. vulagre methanolic extract and B. subtilis SV41 (EMeth+B1) had also significantly improved this parameter by $41.4 \%$ over control. The highest increment in the root fresh weight, of about $50 \%$ relative to control, was noted on plants treated with the combined treatment composed of the aqueous extract and B. amyloliquefaciens subsp. plantarum SV65 (EAq+B2).

When screened for their effects on the flower number, the seven combined bio-treatments led to $54.5-73.7 \%$ increment in this parameter compared to control (Fig. 3a). Also, the fruit fresh weight was significantly increased by $24.2 \%$ over control on eggplant plants treated with $S$. vulgare methanolic extract mixed with $B$. amyloliquefaciens subsp. plantarum SV65 (EMeth+B2) (Fig. 3c).

Comparative efficacy of tested bio-treatments with a compost tea and a commercial bio-fertilizer

Eleven tested bio-treatments, applied singly or in combination, were evaluated for their growth-promoting potential on eggplant seedlings as compared to a compost tea and to a commercial bio-fertilizer (Acadian ${ }^{\mathrm{TM}}$ ).

\section{Aerial part development}

Analyses of variance of all growth parameters measured (plant height, stem diameter, aerial part fresh and dry weights) showed a significant variation (at $\mathrm{P} \leq 0.05$ ) between tested bio-treatments as compared to compost tea- and Acadian ${ }^{\mathrm{Tm}}$ based treatments.

Data showed a significant enhancement by 18.3 to $25.5 \%$ over compost tea based treatment in plant height of eggplant plants treated with $S$. vulgare aqueous extract applied either singly or in combination with both Bacillus spp. strains and/or singly with each tested bacterial strain (Fig. 1a). Furthermore, plants treated with the methanolic extract combined with B. subtilis SV41 and B. amyloliquefaciens subsp. plantarum SV65 (EMeth+B1+B2) were 19.3\% taller than those treated with the compost tea. Similarly, compared with the tested commercial bio-fertilizer, the recorded increment varied from 17.7 to $25 \%$ depending on treatments. The highest increase of plant height, of about $23.4-25.5 \%$ and $23.3-25 \%$ over the commercial bio-fertilizer (i.e. Acadian ${ }^{\mathrm{TM}}$ treat- $^{-}$ ment), were induced by the aqueous extract mixed with $B$. amyloliquefaciens subsp. plantarum SV65 $(E A q+B 2)$ or with both bacterial strains $(E A q+B 1+B 2)$, respectively.

All treatments with $S$. vulgare aqueous extract, applied either singly or in combination with each Bacillus strains separately or both strains combined, showed significant improvement in eggplant stem diameter by $9.9-17.5 \%$ and $11.2-18.7 \%$ over compost 
tea and the commercial bio-fertilizer treatments, respectively (Fig. 1b). B. amyloliquefaciens subsp. plantarum SV65 applied singly (B2) induced a significant increment in this parameter by $12.2 \%$ versus compost tea-based treatment. S. vulgare methanolic extract mixed with $B$. subtilis SV41 (EMeth+B1) led to a significant improvement in the stem diameter by 9.2\% when compared to Acadian ${ }^{\mathrm{TM}}$ based treatment (Fig. 1b). As compared to both tested organic amendments, eggplant plants treated with $S$. vulgare aqueous extract combined with $B$. amyloliquefaciens subsp. plantarum SV65 (EAq+B2) showed an increment by $17.5-18.7 \%$ in this growth parameter.

As shown in Fig. 1c, the aerial part fresh weight was significantly improved by 24.4 to $38.5 \%$ over the compost tea treatment in plants treated separately with the aqueous (EAq) and the methanolic (EMeth) $S$. vulgare extracts, the aqueous one combined with B. amyloliquefaciens subsp. plantarum SV65 $(E A q+B 2)$ or mixed with both Bacillus strains $(E A q+B 1+B 2)$, and the methanolic extract associated with $B$. subtilis SV41 cells (EMeth+B1). Compared to the commercial bio-fertilizer, tested bio-treatments had also significantly improved this parameter by 24.9 to $38.9 \%$. The highest increments in the fresh weight of the aerial part, of about 38.5 and $38.9 \%$ compared to compost tea- and Acadian ${ }^{\mathrm{TM}}$ based treatments, were induced by the aqueous extract combined with $B$. amyloliquefaciens subsp. plantarum SV65 (EAq+B2), respectively.

The aerial part dry weight was enhanced by 26.7$33.4 \%$ and $31.2-37.5 \%$ over the compost tea and the Acadian $^{\text {TM }}$ controls, using $S$. vulgare aqueous extracts either singly or in combination with $B$. amyloliquefaciens subsp. plantarum SV65 and both selected bacterial strains (Fig. 1d). Plants treated singly with the aqueous extract showed the highest increment of this parameter of about 33.4 and $37.5 \%$ compared to those amended with compost tea and Acadian ${ }^{\text {rm }}$, respectively.

\section{Root development}

The maximum root length and the root fresh weight varied significantly (at $\mathrm{P} \leq 0.05$ ) depending on tested bio-treatments. Plants treated with seven biotreatments (the aqueous and methanolic extracts combined with each bacterial strain and/or with both strains and the aqueous extract applied singly) showed significant improvement in the maximum root length of about 15.9 to $37.4 \%$ compared to ones treated with the compost tea (Fig. 2a). As compared to Acadian ${ }^{\text {tm }}$ treatment, nine bio-treatments (same as previously, combined Bacillus spp. strains and $B$. amyloliquefaciens subsp. plantarum SV65 applied singly) induced a significant enhancement by 17.7 to $40.5 \%$ in this parameter. The highest increments of the maximum root length, of about 37.4 and $40.5 \%$ over the compost tea and the commercial bio-fertilizer controls, were induced by $S$. vulgare aqueous extract combined with $B$. amyloliquefaciens subsp. plantarum SV65 (EAq+B2) or with both Bacillus strains (EAq+B1+B2), respectively, (Fig. 2a). The root fresh weight was significantly improved by $32.3 \%$ compared to compost tea using the aqueous extract mixed with $B$. amyloliquefaciens subsp. plantarum SV65 and by 36.1 and $25 \%$ versus Acadian ${ }^{\text {'m }}$ treatment using the last bio-treatment and the methanolic extract combined with $B$. subtilis SV41, respectively (Fig. 2b). The highest increments on this parameter, by 32.3 and $36.1 \%$ compared to compost teaand Acadian ${ }^{\text {tw }}$ based treatments, were induced by the aqueous extract from S. vulgare mixed with B. amyloliquefaciens subsp. plantarum SV65, respectively (Fig. 2b).

\section{Fruit production}

ANOVA analyses performed for the flower number, fruit number and fruit fresh weight showed a significant variation (at $P \leq 0.05$ ) between the eleven bio-treatments tested and compost tea and Acadian ${ }^{\text {TM }}$ based treatments.

As compared to compost tea control, the seven tested bio-treatments had significantly improved the flower number by 40.6 to $59.6 \%$. The highest increase $(59.6 \%)$ was noted on plants treated singly with the aqueous $S$. vulgare extract. Compared to the commercial bio-fertilizer $\left(\right.$ Acadian $\left.^{\mathrm{Tm}}\right)$ ), only the treatment with the algal aqueous extract had significantly enhanced this parameter by $38.3 \%$ (Fig. 3a). This aqueous extract when applied singly had also induced a significant improvement of the fruit number by $40 \%$ compared to compost tea and Acadian ${ }^{\text {Tm }}$ based treatments (Fig. 3b). As shown in Fig. 3c, the average fruit fresh weight was significantly enhanced by 15.8 to $20.8 \%$ over the compost tea control using separately $B$. subtilis SV41, the aqueous and the methanlic $S$. vulgare extracts and the last one combined with $B$. amyloliquefaciens subsp. plantarum SV65. These bio-treatments had significantly improved this production parameter by 35.8 to 
$39.6 \%$ relative to the commercial bio-fertilizer.

\section{Discussion and Conclusions}

The use of eco-friendly resources has been a major focus of attention in the past three decades. Although reports on the benefits of using microbial inoculants for the promotion of plant growth and health in agricultural soil have been inconsistent, there is a promising trend for microbial inoculants to meet the sustainable agricultural production needs (Alori et al., 2017). The use of seaweeds as bio-fertilizers in horticulture and agriculture has increased in the recent years Basmal et al. (2019).

This study was aimed to evaluate the efficacy of combining Bacillus spp. strains and $S$. vulagre extracts (aqueous and methanolic extracts) in order to select the best combination for the bio-stimulation of eggplant growth. Furthermore, bio-treatments (bacteria and algae extracts) tested singly and/or in combination were compared against two organic amendments i.e compost tea and Acadian ${ }^{\mathrm{TM}}$ (a commercial bio-fertilizer) to select the most effective biostimulant among the tested treatments.

Bio-treatments (bacteria and/or algae extract) could be applied either singly as seed priming prior sowing, seedlings root dipping prior transplanting, soil drenching and foliar spraying or combination of two or more methods of application (Papenfus et al., 2013). In this study, bio-treatments either used singly or in combination were applied as seed priming, then seedlings root dipping and finally as substrate drenching. The recommended method, timing and the rate of applications were greatly different according to plant variety and growth stages (Lola-Luz et al., 2013). According to Matysiak et al. (2011) study, the stimulatory potential is more efficient at the early stage of plant growth. In this study, all bio-treatments were applied early at pre-sowing, the first application occurred at the two-true leaf stage and the second one four weeks post-planting.

As single application, the aqueous extract from $S$. vulgare used at $50 \mathrm{~g} / \mathrm{l}$ showed higher growth-promoting potential based on major growth parameters of eggplant than B. subtilis SV41, B. amyloliquefaciens subsp. plantarum SV65 and the methanolic extract compared to the untreated control, and to compost and Acadian ${ }^{\mathrm{Tm}}$ based treatments. As demonstrated by Michalak and Chojnacka (2015), water extraction was found the most effective for better release of micro- and macro-elements from seaweed biomass even used as fertilizer and bio-stimulant. The application of seaweed extracts exhibit stimulating activities of plant growth, yield and fruit quality in a variety of horticultural crops (Battacharyya et al., 2015; Kocira et al., 2018; Mahmoud et al., 2019). Indeed, the use of water extract from algae as plant growth bio-stimulant was described in several crops such as wheat, tomato, Arabidopsis, spinach, and Vigna sinensis and this under normal and stressed environments (Nabti et al., 2010; Craigie, 2011; Kavipriya et al., 2011). In this study, the boiling aqueous extract from S. vulgare at $100^{\circ} \mathrm{C}$ for $1 \mathrm{~h}$ did not affect its growth-promoting potential and the contents of polyphenol and flavonoids (Ammar et al. 2017). Water extracts prepared by autoclaving or heating previously washed marine alga in distilled water are found to have beneficial growth stimulating effects in cereal and flowering plants (Nabti et al., 2010; Craigie, 2011).

The aqueous $S$. vulgare extract applied singly had significantly improved the majority of growth parameters as compared to the untreated control and to the two tested organic amendments. Some seaweeds have been successfully used as soil conditioners and fertilizers in agriculture (Duarte et al., 2018). Commercially, extracts from brown algae such as Acadian are good sources of fertilizer (Hurtado et al., 2008). Fertilizers derived from seaweeds such as Fucus, Laminaria, Ascophyllum, Sargassum etc. are known to be biodegradable, non-polluting and nonhazardous to human and environment (Dhargalkar and Pereira, 2005). Mathur et al. (2015) study demonstrated the benefical effects of seaweed liquid fertilizer from Sargassum wightii, Ulva lactuca and Enteromorpha intestinalis on stimulation of seed germination and growth, and enhancement of biochemical traits of Glycine max plants. Seaweeds extracts were found to be more active than chemical fertilizers in enhancing seed germination and growth parameters (Godlewska et al., 2016). Vasantharaja et al. (2019) found that foliar spraying of cowpea plants with the brown seaweed extract at $3 \%$ significantly improves the shoot length, the number of leaves per plant, yield, the total phenolic and flavonoid contents and the antioxidant activity as compared to control plants. Foliar spray of liquid fertilizer based on $S$ wightii extract has successfully enhanced the chlorophyll content, the internodes and the shoot length of tomato and chilli pepper plants compared to seed soaking (Murugan et al., 2020). The mechanisms of 
stimulation of plant growth by the marine algal extracts may be due to the diverse compounds observed in their extracts. Indeed, macronutrients, organic substances such as amino acids and plant growth regulators substances are presents in the seaweed liquid fertilizer of Sargassum species (Zodape et al., 2008; Nabti et al., 2016; Murugan et al., 2020). Furthermore, seaweed based treatments are able to increase the level of nutrient in soil such as nitrogen, phosphorus and potassium and other compounds as polysaccharides wich are necessary for plant growth that are highly diverse and constitute the major compounds of algae cell walls (Heltan et al., 2015; Mirparsa et al., 2016; Nabti et al., 2016).

To improve the plant growth-promoting ability of both selected Bacillus spp. used in the current study, they were combined either single or in combination with the aqueous and/or the methanolic $S$. vulgare extracts. Microbial inoculants, applied singly or in combination, are able to improve nutrient availability and uptake, and to strengthen plant health (Alori et al., 2017).

As compared to untreated control and to the two tested organic amendments (compost tea and Acadian $^{\mathrm{TM}}$ ), eggplants treated with combined formulations of B. amyloliquefaciens subsp. plantarum SV65 and aqueous S. vulgare extract showed the highest enhancements in plant height, stem diameter, aerial part fresh weight, maximum root length, and root fresh weight. Furthermore, the combination of $B$. subtilis SV41, B. amyloliquefaciens subsp. plantarum SV65 and the aqueous extract had significantly increased the plant height, the stem diameter and the maximum root length as compared to water, compost tea and Acadian ${ }^{\mathrm{TM}}$ based treatments. When applied on seeds, plant surfaces or soil, microbial inoculants are shown able to enhance root exudation, increase the availability and supply essential nutrients to host plants, and thereby promoting their growth (Trabelsi and Mhamdi, 2013). The phytohormones synthetized by microbial inoculants can result in development of the root system, expansion and elongation of the root hairs and lateral roots, leading to improved uptake of water and nutrients (Halpern et al. 2015). Fixation of atmospheric nitrogen, solubilization of minerals such as phosphorus by microbial inoculants are also involved in plant growth promotion (Babalola, 2010). Indirectly, microbial inoculants also affect the status of plants by eliciting the induced systemic resistance (ISR) or the systemic acquired resistance (SAR) thus improving their health. These acts prevent soil-borne pathogens from inhibiting plant growth (Yang et al., 2009). The ability to trigger a salicylic acid (SA)-independent pathway controlling systemic resistance is a common trait of ISR-inducing bio-control bacteria. Both Bacillus spp. used in this study, have been demonstrated as promising bio-stimulants when challenged to tomato plants and their ability to produce the indole-3-acetic acid, organic acids and/or siderophores, to solubilize phosphate, and to control Fusarium wilt disease was evidenced (Aydi Ben Abdallah et al., 2017, 2018).

Plant growth-promoting rhizobacteria (PGPR) applied singly and/or in combination reduced application rates of chemical fertilizers. As demonstrated by Adesemoye et al. (2009), a mixture of PGPR strains B. amyloliquefaciens IN937a and Bacillus pumilus T4, and the arbuscular mycorrhizae (AM) Glomus intraradices added to $75 \%$ fertilizer successfully enhance growth, yield, and nutrient (nitrogen and phosphorus) uptake of tomato plants compared to the $100 \%$ fertilizer control. In the same way, three bio-stimulants consisting of a mix of rhizospheric microorganisms i.e. Pseudomonas sp. 19Fv1T, P. fluorescens $\mathrm{C} 7$ and $\mathrm{AM}$ fungi, tested in conditions of reduced fertilization, induced an increment in the yield, the fruit quality and the nutritional value of tomato fruits (Bona et al., 2018). El-Yazeid et al. (2007) demonstrated that the double inoculation with Paenibacillus polymyxa and Bacillus megaterium associated with a foliar spray of boron led to an enhancement of growth-promoting hormone levels including gibberellic acid, 3-indole acetic acid and cytokinines associated with a decrease in the abscisic acid inhibitor. Double inoculation especially with the mycorrhizal fungus $G$. intraradices and boron spray improved sex ratio and early production of fruits accompanied with high yield of squash.

Several investigations support different aspects of potential macro algal applications in agriculture. Currently, seaweed extracts are the new type of products used in plant cultivation (Elsharkawy et al., 2019). It should be highlighted that the improvement of growth parameters in eggplant plants treated with combined Bacillus spp. and aqueous extract from $S$. vulgare, recorded in the current study, is higher than that induced following the single application of aqueous extract. Hence, the combinations of bio-treatments enhance either the efficacy of bacteria and algal aqueous extract more than when applied singly. However, the combinations of the methanolic extract with tested Bacillus spp. strains did not induce signifi- 
cant increments in the major growth parameters. The synergism occurring between both tested bacterial strains and the aqueous $S$. vulgare extract was confirmed based on various growth parameters. Crocker (2018) investigation clearly demonstrated the in vitro ability of seaweed extract to enhance PGPR growth which may explain the synergism noted. Also, Basmal et al. (2019) found that the biological fertilizer formulation based on Sargassum sp. extract enhance the growth rate of beneficial Pseudomonas fluorescens. Through the in planta experiments, combined PGPR inocula and seaweed extract enhanced significantly the root growth parameters of treated soybean plants compared to the untreated ones (Crocker, 2018). The addition of bio-fertilizer containing multi-strains of Bacillus acting as phosphorus-fixing agents and Azotobacter, Azospirllum and Rhizobium as nitrogenfixing inoculants combined with a foliar spay with mixed seaweed extracts from Ulva lactuca, Ulva faciata and Peterocladia caplicia at $10 \mathrm{ml} / \mathrm{l}$ led to increment of growth characters and to enhancement of the total yield of pea plants (Elsharkawy et al., 2019).

As conclusions, the use of plant-growth promoting bacteria especially Bacillus strains and the brown seaweed extracts (aqueous and methanolic extracts) as bio-stimulants on eggplant plants was emphasized as compared to untreated ones. The combined treatment based on Bacillus spp. strains and the aqueous S. vulgare extract was found to be the most efficient bio-stimulant as compared to a compost tea and a commercial bio-fertilizer tested i.e. Acadian ${ }^{\mathrm{TM}}$. The beneficial roles of the above combined bio-treatments on growth parameters were higher than their single applications. The influence of the combined bio-stimulant developed based on the two tested Bacillus spp. strains and the brown seaweed aqueous extract on the soil microbial community need to be explored in the future to find out ways to more effectively apply this combined bio-treatment and to elucidate its effects on soil microbiome including phytopathogenic and beneficial microorganisms.

\section{Acknowledgements}

This work was funded by the Ministry of Higher Education and Scientific Research of Tunisia through the funding allocated to the research unit UR13AGR09-Integrated Horticultural Production in the Tunisian Centre-East, Regional Research Centre on Horticulture and Organic Agriculture of ChottMariem, Tunisia.

\section{References}

ADESEMOYE A.O., TORBERT H.A., KLOEPPER J.W., 2009 Plant growth-promoting rhizobacteria allow reduced application rates of chemical fertilizers. - Microb. Ecol., 58: 921-929.

ALORI E.T., DARE M.O., BABALOLA O.O., 2017 - Microbial inoculants for soil quality and plant health, pp. 281328. - In: LICHTFOUSE E. (ed.) Sustainable agriculture reviews. Springer International Publishing Switzerland, pp. 304.

AMMAR N., AYDI BEN ABDALLAH R., JABNOUN-KHIAREDDINE H., NEFZI A., RGUEZ S., DAAMIREMADI M., 2017 Sargassum vulgare extracts as an alternative to chemical fungicide for the management of Fusarium dry rot in potato. - J. Agric. Sci. Food Res., 8: 197.

ARIOLI T., MATTNER S.W., WINBERG P.C., 2015 Applications of seaweed extracts in Australian agriculture: past, present and future. - J. Appl. Phycol., 27: 2007-2015.

ARORA N.K., FATIMA T., MISHRA I., VERMA S., 2020 Microbe-based inoculants: Role in next green revolution, pp. 191-246. - In: SHUKLA V., and N. KUMAR (eds.) Environmental concerns and sustainable development. Springer Nature, Sigapore Pte, Ltd, pp. 427.

AYDI BEN ABDALLAH R., JABNOUN-KHIAREDDINE H., NEFZI A., AYED F., DAAMI-REMADI M., 2018 - Endophytic bacteria recovered from Solanum nigrum with plant growth-promoting and Fusarium wilt-suppressive abilities in tomato. - Tun. J. Plant Prot., 13(2): 157-182.

AYDI BEN ABDALLAH R., JABNOUN-KHIAREDDINE H., NEFZI A., AYED F., DAAMI-REMADI M., 2019 - Field suppression of Fusarium wilt and microbial population Shifts in tomato rhizosphere following soil treatment with two selected endophytic bacteria. - Eur. J. Soil Sci., 8(3): 208-220.

AYDI BEN ABDALLAH R., STEDEL C., GARAGOUNIS C., NEFZI A., JABNOUN-KHIAREDDINE H., PAPADOPOULOU K.K., DAAMI-REMADI M., 2017 - Involvement of lipopeptide antibiotics and chitinase genes and induction of host defense in suppression of Fusarium wilt by endophytic Bacillus spp. in tomato. - Crop Prot., 99: 45-58.

AYED F., JABNOUN-KHIAREDDINE H., AYDI BEN ABDALLAH R., DAAMI-REMADI M., 2018 - Sclerotium collar rot suppression and tomato growth promotion achieved using different compost teas. - 5th Int. Conference Sustainable Agriculture and Environment, Hammamet, Tunisia, 5-8 October, pp. 440.

BABALOLA O.O., 2010 - Beneficial bacteria of agricultural importance. - Biotechnol. Lett., 32(11): 1559-1570.

BABALOLA O.O., GLICK B.R., 2012 - Indigenous African agriculture and plant associated microbes: current practice and future transgenic prospects. - Sci. Res. Essays, 7(28): 2431-2439.

BASMAL J., ARIBOWO M.E., NURHAYAT I., KUSUMAWATI R., 2019 - Growth rate of Pseudomonas fluorescens in 
liquid fertilizer from brown seaweed (Sargassum sp.) extracts. - The 1st Int. Conf. Agric. Rural Development, IOP Conf, Earth Env. Sci., 383: 1-10.

BATTACHARYYA D., BABBOHARI M.Z., RATHOR P., PRITHIVIRAJ B., 2015 - Seaweed extracts as biostimulants in horticulture. - Sci. Hortic., 196: 39-48.

BIJARNIYA D., 2011 - Soil amendments, plant extracts and plant products for integrated disease management in agricultural crops. - Afr. J. Agric. Res., 6(33).

BONA E., TODESCHINI V., CANTAMESSA S., CESARO P., COPETTA A., LINGUA G., GAMALERO E., BERTA G., MASSA N., 2018 - Combined bacterial and mycorrhizal inocula improve tomato quality at reduced fertilization. - Sci. Hort., 234: 160-165.

BOTTA A.L., SANTACECILIA A., ERCOLE C., CACCHIO P., DEL GALLO, M., 2013 - In vitro and in vivo inoculation of four endophytic bacteria on Lycopersicon esculentum. New Biotechnol., 30: 666-674.

CARVAJAL-MUÑOZ J.S., CARMONA-GARCIA C.E., 2012 Benefits and limitations of biofertilization in agricultural practices. - Livest. Res. Rural Dev., 24(3).

CRAIGIE J.S., 2011 - Seaweed extract stimuli in plant science and agriculture. - J. Appl. Phycol., 23: 371-393.

CROCKER T.W., 2018 - Evaluation of synergy between $P G P R$ and seaweed extracts for growth promotion and biocontrol of Rhizoctonia solani on soybean. - M.S. Thesis, Auburn University, Alabama, USA, pp. 81.

D'HOSE T., VLIEGHER A.D., BOCKSTAELE E.V., REHEUL D., 2012 - Influence of farm compost on soil quality and crop yields. - Arch. Agron. Soil Sci., 58: 71-75.

DHARGALKAR V.K., PEREIRA N., 2005 - Seaweed: promising plant of the millennium. - Sci. Cult., 71: 60-66.

DUARTE I.J., HERNÁNDEZ S.H.Á., IBAŇEZ A.L., CANTO A.R., 2018 - Macroalgae as soil conditioners or growth promoters of Pisum sativum (L). - Ann. Res. Rev. Biol., 27(6): 1-8.

ELSHARKAWY G.A., HASSAN H.S., IBRAHIM H.A.H., 2019 Effect of promoting diazotrophic bacteria and seaweed extract formula on growth, yield and quality of pea (Pisum Sativum L.) plants. - Alex. Sci. Exch. J., 40: 203217.

EL-YAZEID A.B., ABOU-ALY H.E., MADY M.A., MOUSSA S.A.M., 2007 - Enhancing growth, productivity and quality of squash plants using phosphate dissolving microorganisms (Bio phos-phor ${ }^{\circledR}$ ) combined with boron foliar spray. - Res. J. Agric. Biol. Sci., 3: 274-286.

EYRAS M.C., DEFOSSÉ G.E., DELLATORRE F., 2008 Seaweed compost as an amendment for horticulture soils in Patagonia, Argentina. - Compost Sci. Utiliz., 16(2): 119-124.

GAIND S., 2011 - Microbial inoculants: an approach to sustainable agriculture. - Biotech Article.

GANDHI A., SUNDARI U.S., 2012 - Effect of vermicompost prepared from aquatic weeds on growth and yield of eggplant (Solanum melongena L.). - J. Biofertil Biopesticide, 3(5): 1-4.
GIL, 2015 - L'Aubergine. - Groupement Interprofessionnel des Légumes, Ministère de l'Agriculture et des Ressources Hydrauliques et de la pêche, République Tunisienne.

GODLEWSKA K., MICHALAK I., TUHY A., CHOJNACKA K., 2016 - Plant growth biostimulants based on different methods of seaweed extraction with water. - BioMed Res. Int., 1: 11.

HALPERN M., BAR-TAL A., OFEK M., MINZ D., MULLER T., YERMIYAHU U., 2015 - The use of biostimulants for enhancing nutrient uptake. - Adv. Agron., 130: 141174.

HELTAN M.M., WAKIBIA J.G., KENJI G.M., MWASARU M.A., 2015 - Chemical composition of common seaweeds from the Kenya Coast. - J. Food Res., 4: 28-38.

HURTADO A.Q., TIBUBOS K., CRITCHLEY A.T., 2008 - Use of Acadian marine extract powder from Ascophyllum nodosum in tissue culture of Kappaphycus varieties. - J. Appl. Phycol., 21: 633.

ISMAIL O.M., DAKHLY O.F., ISMAIL M.N., 2011 - Influence of some bacteria strains and algae as biofertilizers on growth of bitter orange seedlings. - Aust. J. Basic Appl. Sci., 5: 1285-1289.

JAGATHEESWARI D., 2013 - Effect of vermicompost on growth and yield of eggplant (Solanum melongena L.). Ind. Streams Res. J., 3(4): 1-6.

KAVIPRIYA R., DHANALAKSHMI P.K., JAYASHREE S., THANGARAJU N., 2011 - Seaweed extract as a biostimulant for the legume crop green gram. - J. EcoBiotech., 3: 16-19.

KOCIRA A., WIECA M., KOCIRA S., ZŁOTEK U., JAKUBCZYK A., 2018 - Enhancement of yield, nutritional and nutraceutical properties of two common bean cultivars following the application of seaweed extract (Ecklonia maxima). - Saudi J. Biol. Sci., 25: 563-571.

LOLA-LUZ T., HENNEQUART F., GAFFNEY M., 2013 - Effect on yield, total phenolic, total flavonoid and total isothiocyanate content of two broccoli cultivars (Brassica oleraceae var italic) following the application of a commercial brown seaweed extract (Ascophyllum nodosum). - Agric. Food Sci., 23: 28-37.

MAGHFOER M.D., SOELISTYONO R., HERLINA N., 2014 Growth and yield of eggplant (Solanum melongena L.) on various combinations of $\mathrm{N}$-sources and number of main branch. - Agrivita, 36(3): 285-294.

MAHMOUD S.H., SALAMA D.M., EL-TANAHY A.M.M., ABD EL-SAMAD E.H., 2019 - Utilization of seaweed (Sargassum vulgare) extract to enhance growth, yield and nutritional quality of red radish plants. - Ann. Agric. Sci., 64: 167-175.

MATHUR C., RAI S., SASE N., KRISH S., JAYASRI M.A., 2015 Enteromorpha intestinalis derived seaweed liquid fertilizers as prospective biostimulant for Glycine max. Braz. Arch. Biol. Technol., 58: 813-820.

MATYSIAK K., KACZMAREK S., KRAWCZYK R., 2011 Influence of seaweed extracts and mixture of humic 
and fulvic acids on germination and growth of Zea mays L. - Acta Sci. Pol. Agric., 10: 33-45.

MICHALAK I., CHOJNACKA K., 2015 - Algae as production systems of bioactive compounds. - Eng. Life Sci., 15: 160-176.

MIRPARSA T., GANJALI H.R., DAHMARDEH M., 2016 - The effect of biofertilizers on yield and yield components of sunflower oil seed and nut. - Int. J. Agric. BioSci., 5: 4649.

MURUGAN A., RUBACATHI A., VISALI K., NEGIMAH V., 2020 - Efficacy of Methylobacterium oryzae supplemented Sargassum wightii liquid fertilizer on chilly and tomato growth. https://doi.org/10.1101/2020.03.16.994640.

NABTI E., JHA B., HARTMANN A., 2016 - Impact of seaweeds on agricultural crop production as biofertilizer. Int. J. Environ Sci. Technol., 14: 1119-1134.

NABTI E., SAHNOUNE M., GHOUL M., FISCHER D., HOFMANN A., ROTHBALLER M., SCHMID M., HARTMANN M., 2010 - Restoration of growth of durum wheat (Triticum durum var. waha) under saline conditions due to inoculation with the rhizosphere bacterium Azospirillum brasilense $\mathrm{NH}$ and extracts of the marine alga Ulva lactuca. - J. Plant Growth Regul., 29: 6-22.

PAPENFUS H.B., KULKARNI M.G., STIRK W.A., FINNIE J.F., VAN STADEN J., 2013 - Effect of a commercial seaweed extract (Kelpak $\left.{ }^{\circledR}\right)$ and polyamines on nutrient-deprived (N, P and K) okra seedlings. - Sci. Hortic., 151: 142-146.

SOWINSKA K.A., KRYGIER M., 2013 - Yield and quality of field cultivated and the degree of fruit maturity. - Acta Sci. Pol. Holturum Cultus., 12(2): 13-23.

SRIDHAR S., RENGASAMY R., 2010 - Significance of seaweed liquid fertilizers for minimizing chemical fertilizers and improving yield of Arachis hypogaea under field trial. - Rec. Res. Sci. Tech., 2: 73-80.

SUNARPI A.J., RINA K., NUR I.J., ALUH N., 2010 - Effect of seaweed extracts on growth and yield of rice plants. BioSci., 2: 73-77.

TRABELSI D., MHAMDI R., 2013 - Microbial inoculants and their impact on soil microbial communities. - BioMed Res. Int., 11.

VASANTHARAJA R., ABRAHAM L.S., INBAKANDAN D., THIRUGNANASAMBANDAM R., SENTHILVELAN T., JABEENB S.K.A., PRAKASH P., 2019 - Influence of seaweed extracts on growth, phytochemical contents and antioxidant capacity of cowpea (Vigna unguiculata $L$. Walp). - Biocatal. Agric. Biotechnol., 17: 589-594.

WASEEM K., HUSSAIN A., JILANI M.S., KIRAN M., GHAZANFARULLAH, JAVERIA S., HAMID A., 2013 - Nutritional management in brinjal (Solanum melongena L.) using different growing media. - Pak. J.Sci., 65(1): 21-25.

YANG J., KLOEPPER J., RYU C., 2009 - Rhizosphere bacteria help plants tolerate abiotic stress. - Trends Plant Sci., 14: 1-4.

ZODAPE S.T., KAWARKHE V.J., PATOLIA J.S., WARADE A.D., 2008 - Effect of liquid seaweed fertilizer and quality of okra (Abelmoschus esculentus L). - J. Sci. Ind. Res., 67: 1115-1117. 